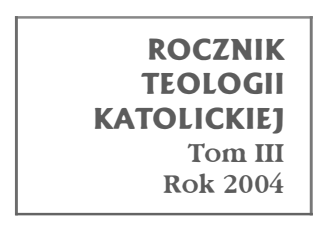

\author{
Ks. Józef Zabielski
}

Uniwersytet w Białymstoku

\title{
EWANGELIZACJA W DOBIE RELIGIJNEGO ZOBOJĘTNIENIA
}

\section{Evangelization in the era of religious indifference}

Spreading the gospel of Christ is a duty of the Church at all times and it pertains to every Christian. The ways and forms of the implementation of this obligation are conditioned by the needs and life circumstances of the people of a given time and culture. Thus we constantly need to examine these signs of the times, so that we may select the most appropriate content and methods of evangelization. These social conditions at times almost force us to revise the current methods and search for new ways of reaching the people of a given era. In all that, on one hand we need to remember the full heritage of faith, and on the other hand we need to pass it on in a way that is clear and convincing. This work, theological and moral in its scope, is an attempt at shedding some light on the circumstances of cultural and religious life specific to our contemporaries, namely on their religious and moral indifference, as well as an attempt at showing the duty to evangelize and the forms of proclaiming Jesus in these circumstances.

Głoszenie Chrystusa i Jego Ewangelii jest powinnością Kościoła wszystkich czasów i skierowane jest do każdego człowieka. Formy realizacji owej powinności w dużym stopniu uzależnione są od potrzeb i okoliczności życia ludzi danego czasu i kultury. Stąd też ciągle należy badać owe „znaki czasu”, aby do nich dostosować treści i metody przepowiadania. Mając to na względzie, papież Paweł VI trzydzieści lat temu przypominał: „Warunki społeczne zmuszają nas wszystkich do zrewidowania metod i poszukiwania z całych sił takich dróg i sposobów, za pomocą których można by ludziom naszego wieku głosić orędzie chrześcijańskie, w którym jedynie będą mogli znaleźć odpowiedź na swe pytania, a także zaczerpnąć siły do wypełniania obowiązków, 
jakie nastręcza wzajemne współżycie ludzi”" Niedługo później, na początku Adhortacji Apostolskiej „Evangelii nuntiandi” podkreślił, że „aby należycie odpowiedzieć na przynaglające nas postulaty Soboru - jest rzeczą konieczną, abyśmy nie tylko mieli przed oczyma dziedzictwo wiary, które Kościół winien przekazywać całe i nienaruszone, lecz także, abyśmy podawali to dziedzictwo dzisiejszym ludziom sposobem możliwie jasnym i przekonującym"2. Mając w pamięci to wezwanie Kościoła, podejmijmy próbę naświetlenia specyficznych uwarunkowań życia kulturowo-religijnego współczesnych nam ludzi, jakimi są sekularyzacja i religijno-moralna obojętność oraz wskazania form i sposobów głoszenia Słowa Bożego w tych okolicznościach i do takich ludzi.

\section{Sekularyzacja i religijna obojętność jako współczesne „znaki czasu"}

Nawet pobieżna próba odczytania „znaków czasu” współczesnej nam kultury i cywilizacji jednoznacznie wskazuje, że charakteryzuje ją sekularyzacja i religijno-moralna obojętność. Przekonanie to podziela wielu obserwatorów, a lokalizację tych fenomenów sytuuje się najbardziej w Europie. „Obojętność religijna - podkreśla kard. Francis Arinze - jest jednym z bardziej godnych uwagi zjawisk naszych czasów, zwłaszcza w kulturze euro-amerykańskiej. Wiele osób żyje tak jakby Bóg nie istniał. Inne zadowalają się powierzchowną religijnością, która nie daje nikomu możliwości dotarcia do zrozumienia kwestii prawdy i odpowiedzenia na swoje solidne wymagania moralne, zwłaszcza w momentach trudności, trudnych wyborów i kryzysów"3. Fakt ten i problem wielokrotnie podkreśla Jan Paweł II. Odnosząc to do naszego kontynentu, przypomina nam „utratę pamięci i dziedzictwa chrześcijańskiego, któremu towarzyszy swego rodzaju praktyczny agnostycyzm i obojętność religijna, wywołująca u wielu Europejczyków wrażenie, że żyją bez duchowego zaplecza, niczym spadkobiercy, którzy roztrwonili dziedzictwo pozostawione im przez historię"4. Choć na zewnątrz w Polsce owego zobojętnienia często się nie zauważa, to Papież także nas uwrażliwia na nie i przed nimi przestrzega. Żegnając się z rodakami w 1991 roku w Warszawie mówił: „Żyjemy tak, jakby Bóg nie istniał, to też część ducha europejskiego. Część europejskiej nowożytnej tradycji. Chrystus [...] został wzięty w nawias i zaczęła się tworzyć inna mentalność europejska, mentalność, którą krótko można wyrazić w zdaniu: »Myślmy tak, żyjmy tak, jakby Bóg nie istniał«"”.

\footnotetext{
${ }^{1}$ Paweł VI, Alokucja do Kolegium Kardynałów, 22.06.1973, AAS 65(1973), s. 383.

" Tenże, Adhortacja A postolska „Evangelii nuntiandi” (dalej skrót: EN), 3.

${ }^{3}$ F. Arinze, Rok Święty: prowokacja ku pokonaniu podziatów i obojętności, w: Jan Paweł II, Tertio millennio adveniente. Komentarz teologiczno-pastoralny $w$ opracowaniu Rady Prezydium Wielkiego Jubileuszu Roku 2000, Sandomierz 1995, s. 277. Por. J. Zabielski, Indyferentyzm religijno-moralny jako „znak czasu”, w: P. Morciniec (red.), Ad libertatem in veritate, Opole 1996, s. 503-520.

${ }^{4}$ Jan Paweł II, Adhortacja A postolska „Ecclesia in Europa” (dalej skrót: EE), 7.

${ }^{5}$ Tenże, Czwarta Pielgrzymka do Polski, Poznań-Warszawa 1991, s. 223.
} 
Przeciwdziałanie takiemu myśleniu i życiowym postawom domaga się ich poznania i interpretacji. Wymienione w tytule dwa zjawiska - sekularyzacja i religijna obojętność - w swej treści mają dużo ze sobą wspólnego i wzajemnie się uzupełniają. Sekularyzacja jawi się jako zasada, fakt i ideologia. W pierwszym znaczeniu stanowi tezę, że nauka, technika i kultura w swym rozwoju winny kierować się „autonomią” bez żadnego związku z religią i teologią. Jako fakt, objawia się wyeliminowaniem czynnika sakralnego z publicznego życia jednostek i społeczności ludzkich. W znaczeniu ideologii identyfikuje się z sekularyzmem, czyli „taką koncepcją świata, według której całkowicie tłumaczy się on sam, bez potrzeby uciekania się do Boga, który staje się zbyteczny, a nawet przeszkadza" ${ }^{(i}$. W tej koncepcji życia usiłuje się podkreślić potęge poznawczą człowieka, co w konsekwencji prowadzi do pomijania Boga lub Jego zaprzeczania. Jest to także przyczyna i zarazem forma spychania religii i Boga do wnętrza życia społeczno-publicznego oraz rozwoju indywidualizmu religijno-moralnego. Objawia się to ateizacją nauki i kultury, postępująca socjalizacją i monopolizacją życia społecznego, rezygnacją z zewnętrznych przejawów religijności, z powiązań między religią i kulturą lokalną lub narodową oraz odrzucaniem tradycyjnych praktyk religijnych i postaw moralnych ${ }^{\top}$.

Drugim - jeszcze bardziej groźnym - zagrożeniem współczesnej cywilizacji jest religijno-moralna obojętność. „Nie ma wątpliwości - pisze M. Neusch Bóg przestaje wchodzić w zakres codziennych trosk ludzi. [...] Bóg ustąpił miejsca innym wartościom: opłacalności, wydajności. Kiedy dawniej pojmowano Go jako tego, który daje sens wszelkiej działalności człowieka, dziś odkłada się Go do lamusa historii. [...] Na płaszczyźnie codzienności ateizm wyraża się więc rosnącą obojętnością, która rozprzestrzenia się, zarażając wszystkie warstwy społeczne. [...] Faktem jest, że coraz więcej ludzi żyje tak, jakby Boga nie było" $"$.

Taka postawa wobec Boga i religii jest groźna zarówno ze względu na swą istotę, jak i zakres. Jest to najbardziej niebezpieczna forma ateizmu, gdyż kwestionuje nie tylko możliwość istnienia Boga i Jego poznania, ale też samo istnienie religii i potrzeb tej natury. Jest to więc postawa całkowicie niedostępna dla dialogu religijnego. Również rozmiary tej postawy stają się coraz bardziej groźne. „To już nie powszechność - podkreśla F. Adamski - to "moda«, styl bycia, coś, czego zdaje się wymagać wykształcenie lub jakiś nowy humanizm”. Inny badacz współczesnego życia społecznego podkreśla, że

${ }^{6} \mathrm{EN}, 55$. Por. Th. Matura, La vie religieuse dans un monde areligieux, „Nouvelle Revue Théologique" 109 (1977), t. 99, nr 1, s. 51-57.

7 Por. J. Majka, Problem sekularyzacji w świetle adhortacji „Evangelii nuntiandi”, „Chrześcijanin w świecie” 1977, nr 58, s. 3-19; W. Kerber, Führungsethik in einer säkularisierten Industriegesellschaft, „Stimmen der Zeit” 112 (1987), t. 205, z. 10, s. 656-658.

${ }^{8}$ M. Neusch, Uźródeł wspótczesnego ateizmu, tł. A. Turowiczowa, Paris 1977, s. 17-18. Por. R. Gibellini, Jenseits des Atheismus, „Concilium” (niem.) 19 (1983), z. 5, s. 401-402.

${ }^{9}$ F. Adamski, Ateizm jako fenomen kulturowy wspótczesnego świata, „Znaki Czasu” 1993, nr 29/30, s. 97. Por. J. Sommet, Indifférence religieuse aujourd'hui, „Projet” 1986, nr 202, s. 86-87. 
indyferentyzm religijno-moralny „wiąże się z pewnymi cechami współczesnej cywilizacji i tzw. nowoczesnej świadomości”, dodając: „Przestaje być on tylko sprawą osobistą członków elit intelektualnych, staje się zjawiskiem historycznym o wymiarach światowych"10.

$\mathrm{Na}$ płaszczyźnie społeczno-kulturowej religijno-moralny indyferentyzm przejawia sięw kilku szczególnych postaciach. Są to:

- tzw. „przemoc kulturowa” („la violance culturelle”) wyrażająca się w różnorakich postaciach brutalności, przemocy i terroryzmu, w czym duże „zasługi” posiadają środki przekazu;

- „przyspieszenie rytmu życia” („l'accélération culturelle du rythme de vie”) lub „obojętność czynu i namiętności” („Gleichgültigkeit der Tat und der Leidenschaft”), czego wyrazem jest hasło: „Czas to pieniądz” (,Times is money”), przyjmujące aksjologiczną zasadę: „Pieniądz jest najważniejszą wartością” („Money is the most important value”);

- „troska o doskonałość” (,sois parfait”) lub „kulturowy perfekcjonizm” (,le perfectionisme culturelle"), polegający na absolutnej potrzebie dostosowania się do mody, stylu i rytmu życia, co uosabiają tzw. idole;

- „przymus sukcesu” (,la contrainte culturelle pour réussir”) osiąganego ‘za wszelką cenę' lub 'po niskiej cenie', gdzie wartości religijno-moralne często są przedmiotem kpiny;

- „nowoczesne zwątpienie” (,neuzeitliche Skepsis”), kiedy to problemy natury religijno-moralnej traktowane są jako pozorne („Scheinfragen”) lub co najwyżej na płaszczyźnie emocjonalnej, a wszystko da się wyjaśnić przy pomocy teorii „logicznego pozytywizmu”;

- „niezdolność do dialogu” („Unfähigkeit zum Dialog”) wyrażająca się wykluczeniem wartości i problemów religijno-moralnych z dialogu, wskazując przy tym, że nawet sami wierzący nie mogą ustalić istoty religii lub ze sobą się porozumieć;

- „obojętność tolerancji” rozumiana jako równouprawnienie wszelkich idei, religii, norm i zachowań ludzkich, gdzie dobro i zło jest kwestią indywidualnych decyzji, a wartości i antywartości są stawiane na tej samej płaszczyźnie aksjologicznej ${ }^{11}$.

${ }^{10}$ J. Mariański, Religia i Kościót w spoteczeństwie pluralistycznym, Lublin 1993, s. 83. Por. W. Obrist, L'Indifférence religiuese symptôme de la mutation de la conscience, „Concilium” (franc.) 1983, nr 185, s. 67-68.

${ }^{11}$ Por. P. Poupard, Non-croyance et cultures d'aujourd'hui, „Nouvelle Revue Théologique” 1983, nr 115, s. 3-21; J. Sommet, Die religiöse Gleichgïltigkeit der Gegenwart. Erster Entwurf einer Diagnose, „Concilium“ (niem.) 19 (1983), s. 330-334; J. J. Pottmeyer, Die Zeichen der Zeit Grund zur Zuversicht?, „Pastoralblatt“ 6 (1993), s. 168-169; K.-H. Weger, Die verdrängte Frage nach Gott. Zum Probleme der religiöse Gleichgültigkeit, „Stimmen der Zeit” 1980, nr 1, s. 33-34; H. R. Schlette, Vom religiösen Indifferentismus zum Agnositizismus, „Concilium” (niem.) 19 (1983), z. 5, s. 371-372; V. Miano, L'Indifférence religieuse. Etude théologique, „Le Point Théologique" 1983, nr 41, s. 14-32; R. Legutko, O tolerancji, w : Z. J. Zdybicka (red.), Religia a sens bycia człowiekiem, Lublin 1994, s. 113-132; J. Zabielski, Tolerować czy kochać, „Głos Katolicki. Voix Catholique" 36 (1994), nr 10, s. 1 i 7. 
Na płaszczyźnie ideowo-moralnej religijny indyferentyzm objawia się niezdolnością sprostania problemowi prawdy i obowiązkowi zachowania spójności między życiem a wymogami etyki. Wiąże się to z utratą poczucia transcendentnego sensu ludzkiej egzystencji i zagubieniem na polu etyki, obejmującym nawet tak fundamentalne wartości, jak szacunek dla życia i rodziny ${ }^{12}$. Takie myślenie przejawia się w kilku charakterystycznych postawach:

- niechęć i opór wobec obietnic wiary, które jawią się jako „mdłe” i „nierealne”, gdyż nie gwarantują żadnego szczęścia w przyszłości oraz nie rozwiązują podstawowych problemów życia ziemskiego, jak np. cierpienia, ubóstwa itp.;

- „obojętność metodyczna” lub „naukowa” („überlegte Gleichgültigkeit”), pokładająca absolutną ufność w nauce i technice, które nie zajmują się Bogiem, religią i moralnością, stąd też należy je uznać za pojęcia irracjonalne;

- „doświadczenie pustki i nieobecności” („Erfahrung der Leere und der Abwesenheit”), prezentowane przez wielu ludzi młodych, którzy żyją „na luzie” w przekonaniu, że ludzka egzystencja sama w sobie jest „pusta”;

- „obojętność destrukcji” („Gleichgültigkeit der Zersetzung”) polegająca na zupełnym braku zainteresowania życiem „tu i teraz”, traktująca wszystko jako „całkowity bezsens” („Quatsch”);

- „zerwanie więzi międzyludzkich” („Abkehr von jeder mitmenschlichen Beziehung"), gdyż uznaje się je za bezsensowne, co prowadzi do zaniku empatii i postaw terrorystycznych;

- „obojętność młodości” („Gleichgültigkeit der Jugend”) to postawy typu: „jeszcze mi na niczym nie zależy”, ,jeszcze mi wszystko wolno” itp. Choć jest to postawa bardzo niebezpieczna, to nadzieję budzi fakt, że często przemija wraz z młodością ${ }^{13}$.

\section{Sekularyzm i indyferentyzm jako ewangelizacyjne wyzwanie}

Wymienione tu formy myślenia i egzystencjalne postawy ukazują podstawowe sposoby przejawiania się religijno-moralnego indyferentyzmu we współczesnym świecie. W konsekwencji „sfera "profanum« uwalnia się od związków ze sferą "sacrum«, religia nie determinuje już życia codziennego, które

${ }^{12}$ Por. Jan Paweł II, List Apostolski, „Tertio millennio adveniente”, 36.

${ }^{13}$ Por. P. Colin, L'indifférence religieuse. Discours anciens, questions nouvelles, „Etudes” 1985, nr 3, s. 397-398; G. Piétri, L'indifférence religieuse : un aboutissement. Ses causes et ses limites, „Etudes” 1989, nr 4, s. 374-375; G. Girardi, Uwagi o objetności religijnej, „Conilium. Międzynarodowy Przegląd Teologiczny" 1966/67, nr 1-10, s. 117-118; K.-H. Weger, Die verdrängte Frage nach Gott, dz. cyt., s. 35-36; X. Tilliette, Inquietude humaine et incroyance, „Nouvelle Revue Théologique" 1984, nr 106, s. 161-172; J. Sommet, Die religiöse Gleichgültigkeit der Gegenwart, dz. cyt., s. 332-333 ; R. Bleinstein, Jugend ohne Religion?, „Stimmen der Zeit” 117 (1992), t. 210, z. 9, s. 577; G. Lescanne, Maturation humaine et croissance de la foi, „Christus. Cahiers spirituels" 37 (1990), nr 146, s. 138-140; J. Mariański, Młodzież między tradycja a ponowoczesnościq, Lublin 1995, s. 205-240. 
poddane jest »logice« wartości doczesnych. Laicyzacja spontanicznie prowadzi do osłabienia więzi religijnych i kościelnych, postaw indyferentnych wobec wszelkiej Transcendencji, aż do postaw ateistycznych" ${ }^{14}$.

Już ta prosta konstatacja ukazuje normatywny charakter sekularyzmu i obojętności religijno-moralnej. Doświadczenie owej powinności ukazuje się jeszcze bardziej, gdy dokładniej poznajemy skutki tego fenomenu. Szczególnie widać je w odniesieniu do trzech fundamentalnych wartości: prawdy, dobra i Sacrum.

Stosunek indyferentyzmu do kategorii prawdy objawia się zanegowaniem jej istnienia i potrzeby odkrywania. Najczęściej przyjmuje to postać agnostycyzmu poznawczego i oddzielenia prawdy od egzystencji - poznania od działania. „Miejsce pewności wielkich prawd wiary u wielu ludzi zajęło niejasne i mało zobowiązujące uczucie religijne; szerzą się różne formy agnostycyzmu i praktycznego ateizmu, które przyczyniają się do pogłębienia rozdźwięku między wiarą a życiem"15.

W stosunku do kategorii dobra indyferentyzm przejawia się immanentyzmem i relatywizmem moralnym, fałszywym rozumieniem i przezywaniem wolności oraz błędnym wartościowaniem dobra i zła moralnego. W konsekwencji, „jesteśmy świadkami swego rodzaju sekularystycznej interpretacji wiary chrześcijańskiej, która powoduje erozję i z którą wiąże się głęboki kryzys sumienia i praktyki moralności chrześcijańskiej ${ }^{16}$.

W odniesieniu do Sacrum ludzie obojętni prezentują agnostycyzm lub tzw. „wiarę ogólną”. „Osoby obojętne w sprawach wiary mogą niekiedy uznawać w sposób czysto spekulatywny istnienie Siły Wyższej, ale ta wiara nie oddziaływuje na ich konkretne, osobiste życie" ${ }^{17}$. Sytuację tę Jan Paweł II charakteryzuje następująco: „Wielu współczesnych Europejczyków sądzi, że wie, co to jest chrześcijaństwo, ale w rzeczywistości go nie zna. Często nawet podstawy i najbardziej zasadnicze pojęcia chrześcijaństwa nie są już znane. Wielu

${ }^{14}$ J. Mariański, Laicyzacja jako fakt społeczny, „Universitas Gedanensis” 13 (2001), nr 23, S. 47.

${ }^{15}$ EE, 47. Por. A. Siemianowski, Człowiek i prawda, Poznań 1986, s. 11-12; D. von Hildebrand, Gesammelte Werke, t. 7, Regensburg 1974, s. 312-318; J. Sommet, Die religiöse Gleichgültigkeit der Gegenwart, dz. cyt., s. 330-331; H. R. Schlette, Vom religiösen Indifferentismus zum Agnostizismus, dz. cyt., s. 371-372; H. Jonas, Agnostcyzm, egzystencjalizm, nihilizm, „Libertas” 188, nr 101, s. 36-58; F.-X. Kaufmann, Wahrheit als Problem, „Herder Korrespondenz" 45 (1991), z. 8, s. 345-347; G. Thils, La présence de Dieu dans un monde planétaire et pluraliste, „Nouvelle Revue Théologique” 1986, nr 6, s. 878-879.

${ }^{16} \mathrm{EE}, 47$. Por. G. de Rosa, Indifférence religieuse et sécularistation, „Le Point Théologique” 1983, nr 41, s. 179-180 ; J. Doré, Ethique, religion et foi, „Le Point Théologique” 1985, nr 43, s. 16-21; R. Bleistein, Individualisierung und Identität, „Stimmen der Zeit” 1992, t. 210, z. 10, s. 665-667; P. Góralczyk, Możliwość ślepoty na wartości moralne, w: Zło w świecie. Kolekcja Communio, Poznań 1992, s. 320-331; J.-L. Brugues, L'éthique dans un monde désenchanté, „Revue Thomiste” 1994, t. 44, nr 2, s. 198-200; J. Ratzinger, Die Beduetung religiöser und sittlicher Werte in der pluralistischen Gesellschaft, „Concilium” (niem.) 21 (1992), nr 6, s. 500-501.

${ }^{17}$ J. Mariański, Religia i Kościót w spoteczeństwie pluralistycznym, Lublin 1993, s. 83. Por. P. Valadier, Société moderne et indifférence religieuse, dz. cyt., s. 66-67; J. Sommet, Die religiöse Gleichgültigkeit der Gegenwart, dz. cyt., s. 331-332. 
ochrzczonych żyje tak, jakby Chrystus nie istniał; powtarza się gest i znaki związane z wiarą, zwłaszcza w praktykach religijnych, ale nie odpowiada im rzeczywista akceptacja treści wiary i przylgnięcie do Osoby Jezusa"18.

Choćby tak pobieżne poznanie skutków sekularyzmu i obojętności religijnej pozwala doświadczyć powinności poszukiwania dróg dojścia do osób podzielających wymienione poglądy i życiowe postawy. Ten problem zauważa dziś wielu badających analizowaną tu rzeczywistość. „Nowa forma ateizacji podkreśla J. Mariański - niosąca zeświecczenie moralności motywowanej religijnie będzie poważną troska Kościoła w XXI wieku. [...] Struktury demokratyczne wykluczają centralną pozycję religii w życiu publicznym i znaczące wpływy Kościoła w społeczeństwie" ${ }^{19}$. Jan Paweł II odczytuje to jako najbardziej naglące zadanie współczesnego Kościoła, zwłaszcza na naszym kontynencie. „Kościele w Europie - przypomina i apeluje - czeka cię zadanie nowej ewangelizacji! Umiej odnaleźć entuzjazm głoszenia. [...] Niech zatem głoszenie Jezusa, które jest Ewangelią nadziei, będzie twą chlubą i racją twego istnienia"”o().

\section{Sposoby i formy głoszenia Ewangelii ludziom obojętnym}

Ewangelizacyjna powinność wobec religijnego zobojętnieniem winna być „przełożona” na konkretne formy i sposoby głoszenia Chrystusa, pozwalające dotrzeć do ludzi obojętnych na Boga i Jego wolę. Jest to zadanie niezwykle trudne i złożone, uzależnione od szeregu czynników i uwarunkowań. Przede wszystkim zależne jest od podmiotów ewangelizacji i od jej adresatów. Inaczej bowiem winna przedstawiać się ewangelizacja ludzi obojętnych w stopniu absolutnym, innej zaś formy oddziaływań potrzebują ci, którzy wykazuja tylko częściowe lub względne zobojętnienie. Mając to na względzie Jan Paweł II stwierdza: „Faktycznie Europa należy obecnie do tych miejsc tradycyjnie chrześcijańskich, w których konieczna jest nie tylko nowa ewangelizacja, ale w pewnych przypadkach również pierwsza ewangelizacja"21.

Pierwszym sposobem głoszenia Ewangelii ludziom dotkniętym obojętnością jest samo dostrzeżenie ich istnienia i zainteresowanie się nimi. Niestety, należy ze smutkiem podkreślić fakt, że dotychczas zbyt mało zwraca się uwagi na istnienie religijno-moralnego zobojętnienia, zwłaszcza w Polsce. Potwierdzeniem tej tezy niech będzie brak ogólnopolskich badań życia religijno-moralnego ostatniego czasu² ${ }^{22}$ Brak znajomości stanu faktycznego uniemożliwia opracowywanie środków działania. Niech mobilizacją będzie wezwanie Jana Pawła II: „Kościół nie może zaniedbać obowiązku postawienia odważnej dia-

${ }^{18} \mathrm{EE}, 47$.

19. J. Mariański, Laicyzacja jako fakt społeczny, dz. cyt., s. 56.

${ }^{20} \mathrm{EE}, 45$

${ }^{21}$ Tamże, 46.

22. Wycinkowe - choć bardzo ważne - badania w tym względzie prowadzą profesorowie: J. Mariański (Lublin KUL) i W. Zdaniewicz (Warszawa ATKUKSW). Bardzo cenna pozycją w tym zakresie jest pr. zb. pod red. J. Mariańskiego pt. „Kondycja moralna społeczeństwa polskiego”, Kraków 2002. 
gnozy, która pozwoliłaby na zastosowanie odpowiedniej terapii. Również na "starym kontynencie» są rozległe obszary społeczne i kulturalne, na których jest konieczna prawdziwa misja ad gentes"'3.

Niestety, częściej mówi się o potrzebie i sposobach głoszenia Ewangelii tym, którzy nie mieli możliwości poznania Chrystusa, tych zaś, którzy wykazują obojętność traktuje się też „obojętnie”"4. Z pewnością przyczyną jest tu trudność porozumienia się z osobami obojętnymi, czyli brak zainteresowania $\mathrm{z}$ ich strony Bogiem i religią. Tego rodzaju trudność nie mobilizuje do zainteresowania się ludźmi obojętnymi, stawiając ich z góry na pozycji straconej. Faktem jest, że łatwiej ewangelizować poszukujących Boga i otwartych na Jego działanie niż tych, którzy nie wykazują zainteresowania wartościami religijno-moralnymi. Pierwszym więc sposobem głoszenia Ewangelii takim osobom jest dostrzeżenie ich i „wyłowienie z tłumu” oraz próba nawiązania relacji typowo osobowych. Do tego rodzaju oddziaływań ewangelizacyjnych należy też zaliczyć badania naukowe nad sekularyzmem i indyferentyzmem religijnym, zwłaszcza metodami socjologii o psychologii moralnościi.

Kontakt z osobami obojętnymi powinien przyjmować postać dialogu. Jest to metoda, którą prezentuje i proponuje Kościół, będąc przekonany, że kontakt z ludźmi niewierzącymi nie może obyć się „bez szczerego i roztropnego dia$\log \mathrm{u}^{26}$. Jest to najbardziej skuteczna i potrzebna forma ewangelizacji, która „stanowi dla Kościoła w pewnym sensie środek, a nade wszystko sposób wypełniania jego działalności w świecie współczesnym"27. Wszystkie więc formy ewangelizacji osób religijnie obojętnych winny przejawiać cechy dialogu, gdyż taki charakter posiada cała misja zbawcza Kościoła, będącego kontynuacją posłannictwa tego, który sam jest „Wcielonym Dialogiem”28. „Dla wszystkich powinno być jasne - podkreśla Jan Paweł II - że Kościół chce prowadzić dialog ze wszystkimi, także z tymi, którzy się od niego oddalili i odrzucają go zarówno w swoich stanowczo głoszonych przekonaniach, jak i w zdecydowanych, czasami nawet bojowych postawach"'?. Do ludzi obojętnych, zagubionych, tracących sens życia, zmagających się z pytaniami i wątpliwościami, należy najpierw wyjść z Ewangelią w postaci interpersonalnego dialogu. Winien on przyjąć postać szczerego, opartego na wzajemnym

$23 \mathrm{EE}, 46$.

${ }^{24}$ Por. J. F. Six, Zbliżenie wierzących i niewierzących, „Chrześcijanin w świecie” 23 (1973) nr 3, s. 75-76.

${ }^{25}$ Por. J. Doré, Ethique, religion et foi, dz. cyt., s. 22-23.

${ }^{26}$ Sobór Watykański II, Konstytucja „Gaudium et spes” (dalej skrót: KDK), 21.

${ }^{27}$ Jan Paweł II, Adhortacja Apostolska „Reconciliatio et paenitantia”, 25. Por. J.-Y. Calez, Vatican II il a 20 ans. Portée des prises de position sur la non-croyance, "Nouvelle Revue Théologique” 1985, nr 2, s. 179-180 ; S. Wilkanowicz, Ateizm-ewangelizacja-demokracja, „Znak” 42 (1990), nr 424, s. 22-24.

28 Por. KDK 21; K. Czulak, Wiara wobec wyzquania niewiary, „Communio” (pol.) 1 (1981), nr 4, s. 8-9.

¿9 Jan Paweł II, Przemówienie do uczestników Kongresu „Ewangelizacja a ateizm”, w: Nauczanie papieskie, III, 2, 1980, Poznań-Warszawa 1986, s. 451. 
zaufaniu, poszukiwania dróg wyjścia z deklarowanych niebezpieczeństw. Dialog ten ma być wspólnym poszukiwaniem prawdy, a jego źródłem jest zakorzeniona w Bogu miłość człowieka. Jest to fundamentalna forma ewangelizacji ludzi obojętnych, gdyż „Kościół musi człowieka poznać poznaniem zakorzenionym w miłości, które usposabia do szczerego i opartego za zaufaniu dialogu, dialogu ludzi rozdzielonych przez swe przekonania, ale zbliżających się ku sobie dzięki tej samej miłości człowieka"30.

Ewangelizacyjny dialog winien mieć na uwadze konkretnego człowieka całą prawdę o nim i jego dobro. Nie wolno ludzi religijnie obojętnych zostawiać samym sobie, gdyż nie można „pozostawać niewrażliwym na dramat ateistycznego humanizmu, którego antyteizm, a ściślej antychrystianizm, doprowadza do przygniecenia osoby ludzkiej, którą chciał może uwolnić od ciężkiego brzemienia Boga, uważanego za ciemięzcę" 31 . W dialogu tym trzeba dążyć do wykazania, że człowiek organizujący życie ziemskie bez Boga ostatecznie działa przeciw sobie. Humanizm bowiem, pozbawiony transcendentnego wymiaru, staje się nieludzki i niszczący. Każdy więc przejaw ateistycznego humanizmu winien stać się inspiracją „do odnajdywania w starzejącym się świecie całej mocy nowości zawsze nowej Ewangelii, tego niewyczerpanego źródła odnowienia" "32. Celem więc owego dialogu jest ukazywanie Ewangelii jako podstawy ładu wewnętrznego i zewnętrznego ludzkiej egzystencji oraz fundamentalnego sposobu ochrony człowieka i jego godności we współczesnym świecie.

Z pewnością - przynajmniej na początku - dialog taki nie będzie miał charakteru tradycyjnej działalności duszpasterskiej. Eksponowanie bowiem religii w początkowych kontaktach z ludźmi obojętnymi może objawiać się ich zamknięciem, a nawet wrogością. Stąd też, szanując wolność i autonomię osoby, w odpowiednich momentach trzeba podsuwać pytania dotyczące „wielkich niewiadomych” ludzkiego życia i śmierci. Niekiedy właściwym sposobem nawiązania tego rodzaju kontaktu może być swego rodzaju „prowokacja”, której celem jest doprowadzenie do zainteresowania treściami religijnomoralnymi. Taki sposób ewangelizowania na terenach ZSRR prowadził, zamordowany w 1990 roku, prawosławny duchowny ks. Aleksander Mień. „Głosił prawdę o Bogu w różny sposób. Gdy napotykał sprzeciw, stosował apologię, gdy znajdował niezrozumienie, uprawiał hermeneutykę, gdy dostrzegał obojętność, prowokował i prowadził dialog"33.

${ }^{30}$ Tamże. Por. J. Zabielski, Wspótczesny indyferentyzm religijno-moralny jako problem dialogu, w: J. Baniak (red.), Filozofia dialogu, t. 1, Poznań 2003, s. 224-225.

${ }^{31}$ Jan Paweł II, Przemówienie „Ewangelizacja a ateizm”, dz. cyt., s. 453. Por. J. Sommet, Indifférence et espoirs Europe, „Etudes” 1986, nr 3, s. 243-254.

32. Jan Paweł II, Przemówienie „Ewangelizacja a ateizm”, dz. cyt., s. 543. Por. J. Zabielski, Wspótczesny indyferentyzm religijno-moralny jako problem dialogu, dz. cyt., s. 225-226.

${ }^{33}$ T. Pikus, Aksjologiczny wymiar religii w twórczości Aleksandra Mienia, Warszawa 1998, s, 25. Por. A. Delzant, La foi provoquee par l'inroyance, w: L. Collin (red.), Foi chrétienne et non-croyances : quel dialogue?, Angers Cedex 1994, s. 141-152. 
Należy pamiętać o tym, że wielu współczesnych ludzi swój sposób myślenia i działania przyjmuje bez głębszej refleksji i wewnętrznej akceptacji, nie starając się poznać sensu i znaczenia tego dla swego życia. W konsekwencji ludzie ci mogą nie wykazywać zainteresowania wartościami religijno-moralnymi, choć nigdy poważnie się nad tym nie zastanawiali, nie umieją też uzasadnić swej obojętności ani nie uświadamiają sobie jej skutków. W głębi serca pozostają więc osobami poszukującymi i noszącymi nie nazwane pragnienie całościowego sensu swej egzystencji. Inni zaś wykazują „znudzenie” poszukiwaniem owego sensu i prawdy o sobie i świecie, ale nie widzą już możliwości jej osiągnięcia; sami nie dają sobie rady, a nie spotkali nikogo, kto by im pomógł. Niewątpliwie wiary i systemu moralnego nie da się budować na ludzkich rozczarowaniach czy porażkach, ale mogą one posłużyć do kolejnej próby zrozumienia, że człowiek nie może się zrealizować wyłącznie w oparciu o własne siły. To zaś może prowadzić do wniosku, że człowiek jako byt osobowy winien poznawać i poświęcać siebie temu, co jest ponad nim i co go „wznosi” wyżej ponad widzialny świat. Uwrażliwienie człowieka obojętnego na tego rodzaju problemy, pomoc w stawianiu egzystencjalnych pytań oraz wspólne poszukiwanie na nie odpowiedzi, to sposoby prowadzenia ewangelizacyjnego dialogu z osobami indyferentnymi i poddanymi sekularyzacji ${ }^{34}$. Przywołany tu ks. A. Mień „w kontaktach z ludźmi starał się najpierw wniknąc w świat zainteresowań rozmówcy, w jego poglądy, aby wychodząc od nich pokazać mu inne, wyższe wartości"35.

Rozbudzony religijno-moralny niepokój należy w osobach obojętnych podtrzymywać i rozwijać, dostarczając mu odpowiednich treści. Na tym etapie ewangelizacji trzeba zatroszczyć się o właściwe przedstawienie Boga i religii oraz wynikającej stąd moralności. Ludziom obojętnym, którzy wykazali pewne otwarcie na Boga należy od razu ukazywać prawdziwy, tj. ewangeliczny obraz Boga i jego woli wobec człowieka. „Ateistom i cywilizacji, która odrzuca transcendencję - podkreśla S. Rosik - trzeba przeciwstawić egzystencję Boga takiego, jaki On jest w rzeczywistości. Afirmacja Boga wynika nie tylko z powołania się na przesłanki rozumu i znaki natury (jest to pierwsze Słowo Boga do człowieka), ale z przekonania wiary i świadectwa Boga, którego Imię brzmi: "Ja jestem, który jestem «"36. Posługiwanie się bowiem jakimiś zastępczymi czy infantylnymi pojęciami (także przykładami kaznodziejskimi) może mieć zgubne następstwa i jeszcze bardziej utrwalić owo zobojętnienie. Jest to tym bardziej potrzebne dziś, gdy funkcjonuje szereg błędnych i fałszywych treści i postaw w tym względzie, czego przykładem są sekty. Przedstawienie

34 Por. E. Biser, Religiöse Spurensuche. Chistentum in postsäkularistischer Zeit, „Stimmen der Zei” 111 (1986), t. 204, z. 9, s. 609-621; J. Sommet, Indifférce et espoirs en Europe, dz. cyt., s. 254-255.

35 T. Pikus, Aks jologiczny wymiar religii w twórczości Aleksandra Mienia, dz. cyt., s. 25.

${ }^{36} \mathrm{~S}$. Rosik, Sumienie - problem żywotny wspótczesności, w: P. Morciniec (red.), Ad libertatem in veritate, dz. cyt., s. 121. Por. F. Laplanche, La Bible, parole de Dieu au parole hurnaine?, w: L. Collin (red.), Foi chrétienne et noncroyances: quel dialogue?, dz. cyt., s. 87-912. 
zaś prawdziwego obrazu Boga i religii domaga się od głoszących te prawdy dobrej znajomości Biblii i nauk filozoficzno-teologicznych. Pozwoli to uniknąć ewentualnych błędów i dostarczy właściwych argumentów w tym zakresie. Ewangelizator winien też dysponować odpowiednią wiedzą ogólną, a zwłaszcza z zakresu nauk historyczno-społecznych i psychologiczno-pedagogicznych, aby mógł sprostać stawianym pytaniom oraz ewentualnym zarzutom pod adresem Boga, religii i moralności. Liczy się też sposób argumentacji - logika rozumowania, a równocześnie trafne i praktyczne odniesienia owych argumentów do życia konkretnej osoby czy wspólnoty. W owej argumentacji ważne jest odwoływanie się do argumentów naturalno-racjonalistycznych oraz wskazanie na negatywne skutki błędnych pojęć i postaw. Ważny też jest sposób traktowania interlokutora oraz „trafienie” w jego zainteresowania i sposób rozumowania $^{37}$.

Religijna obojętność często jest nieodłącznie związana z problemami moralnymi danej osoby. Stąd też ewangelizowanie należy zacząć od zagadnień moralno-egzystencjalnych. Jeżeli stwierdzamy, że dany człowiek tak się zagubił w życiu moralnym, że stało się to przyczyną jego obojętności w tym zakresie, a tym bardziej wobec Boga i religii, to najpierw trzeba mu pomóc odzyskać równowagę moralną, która będzie stanowić podstawę nawiązania osobowego kontaktu z Bogiem. Tego rodzaju proces należy zacząć od pojednania tego człowieka ze stworzeniem, następnie z innymi ludźmi, gdyż człowiek „pogodzony z kosmosem” będzie mógł nauczyć się „szanować wartość każdej ludzkiej osoby, stworzonej na podobieństwo Boga i odkupionej przez Chrystusa" 38 . Ostatni etap to pojednanie danego człowieka z sobą samym, co domaga się ukazania mu integralnej wizji egzystencji człowieka w świecie, która zdolna będzie przeciwstawić się przeżywanemu zwątpieniu.

W takim oddziaływaniu ewangelizacyjnym najpierw należy odwoływać się do prezentowanego poziomu świadomości, której „nie można sprowadzić do oddziaływujących na nią warunków. Jest to świadomość zdolna do poznania swej godności i otwarcia się na absolut; świadomość będąca źródłem fundamentalnych wyborów, którymi kieruje poszukiwanie dobra - zarówno dobra innych, jak i własnego; świadomość ta jest miejscem odpowiedniej wolności"3!". Odwołanie się do tej podstawowej świadomości bytu osobowego jest jak najbardziej zasadne, gdyż ta powszechna zdolność jest źródłem fundamentalnych wyborów moralnych i ukierunkowuje obie strony owego spotkania na wartość

${ }^{37}$ Por. M. Soetard, Dialogue et vérité, dialogue et violance, w: L. Collin (red.), Foi chrétienne et noncroyances: quel dialogue?, dz. cyt., s. 172-178; H. Bürkle, Das europäische Christentum und die nichtchristliche Kulturen, „Stimmen der Zeit” 109 (1984), t. 202, z. 9, s. 607-608.

38 Jan Paweł II, Przemówienie do Zgromadzenia Parlamentarnego Rady Europy w Strasburgu, 08.10.1988, „L'Osservatore Romano” (pol.) 9 (1988), nr 10-11, s. 5. Por. B. Piwowarczyk, La foi conrfontée a l'indifférence et a l'atheisme, Paris 1989, s. 44-47.

${ }^{39}$ Jan Paweł II, Przemówienie do Zgromadzenia Parlamentarnego Rady Europy, dz. cyt., s. 5. Por. C. Dagnes, La liberté et la pasion du dialogue, w: L. Collin (red.), Foi chrétienne et noncroyances: quel dialogue?, dz. cyt., s. 237-238. 
osoby, upatrując w niej „miejsce” spotkania etyki świeckiej z moralnościa religijną, a w dalszej konsekwencji z Bogiem i jego wolą. Celem zaś tego ewangelizacyjnego dialogu ma być doprowadzenie do przekonania, że norm moralnych i wartości osoby ludzkiej nie da się w pełni uzasadnić bez wyraźnego lub ukrytego odniesienia do Boga. Tylko bowiem w Bogu zarówno osoba jak, i jej moralność uzyskują pełnię prawdy o sobie i charakter normatywny, szanujący ludzką godność. Uznanie zaś owej wartości i godności każdej osoby ludzkiej jawi się jako fundament wszelkiej refleksji nad tym minimum etycznym wspólnym wszystkim ludziom, na płaszczyźnie wielości propozycji moralnych we współczesnym świecie. Wartość i godność osoby winna więc stać się „punktem zaczepienia” w dialogu prowadzącym do otwarcia się na Boga i Jego zbawczą wolę. Stąd też zasadne jest konsekwentne ukazywanie znaczenia i norm etyki chrześcijańskiej, która ukazuje integralną wizję osoby ludzkiej i zdolna jest obronić człowieka przed niszczącym nihilizmem i hedonizmem, jakże często obecnym w życiu ludzi religijnie obojętnych ${ }^{40}$.

Niezwykle ważnym i zawsze aktualnym sposobem głoszenia Ewangelii jest świadectwo życia. Wszyscy podejmujący wysiłek ewangelizacyjny winni mieć w pamięci, że „w Kościele za pierwszy środek ewangelizowania należy uważać świadectwo życia prawdziwie i ściśle chrześcijańskiego, które trwa w nierozłącznej wspólnocie z Bogiem, a zarazem w nieograniczonej gorącości ducha poświęcenia się dla innych" ${ }^{41}$. Jest ono szczególnie znaczące w odniesieniu do ludzi religijnie obojętnych, dla których treść przepowiadania najczęściej zajmuje miejsce dalsze, na pierwszym zaś miejscu jest osoba przepowiadającego, jego wiara i świadectwo życia. Równocześnie głoszący Słowo Boże winien być skromny w prezentowaniu swych przekonań i swej moralności, nie zaś jawić się jako agitator lub głosiciel ideologii. Ma prezentować się jako ten, kto przekazuje poznany depozyt, czyniąc to z „cierpliwością i nauką”, podnosząc na duchu, a równocześnie wykazując błędy i pouczając (por. 2Tym 3,10; 4, 1-2) ${ }^{42}$. Wszystko zaś powinno być przepojone miłością do Boga i człowieka oraz życzliwością w poszukiwaniu jego dobra. M. Delbrel, która wiele lat spędziła wśród ludzi niewierzących i obojętnych stwierdza, że „nic na świecie nie da nam dostępu do serca naszego bliźniego oprócz faktu, że daliśmy Chrystusowi dostęp do naszego serca"4:3. Dobroć Chrystusowego serca, którą będziemy mogli przekazać człowiekowi obojętnemu ma dla niego „nieznany smak Boga

${ }^{40}$ Por. M. Vidal, Absolutna wartość osoby miejscem spotkania i zespolenia etyki świeckiej z moralnościa religijna, w: Moralność chrześcijańska. Kolekcja Communio, Poznań-Warszawa 1987, s. 125-142; J. Römelt, Verkündigung moralischer Normen. Pastoral Dienst und menschlicher Problem, „Stimmen der Zeit” 115 (1990), t. 208, z. 6, s. 402-405; J. Rief, Moralverkündigung angesichts der krise der Moral, „Theologisch-Praktische Quartalschrift” 117 (1969), z. 2, s. 124-128.

${ }^{41} \mathrm{EN}, 41$.

${ }^{42}$ Por. J. Loew, Osobisty kontakt duszpasterski z niewierzacymi, „Concilium. Międzynarodowy Przegląd Teologiczny" 1966/67, nr 1-10, s. 132-133.

${ }^{43}$ Cyt. za: J. Loew, Osobisty kontakt duszpasterski z niewierzacymi, dz. cyt., s. 133. 
i uwrażliwia na Jego spotkanie. Jest ona dla niewierzącego niezwykła, związana z tym niezwykłym absolutem, którym jest dla niego Bóg. Budzi, nawołuje uśpione siły jego serca, siły nie znane mu, których żywą rzeczywistość odnajduje on w sobie. Współbrzmi ona z tym, co w sercu niewierzącego jest zarazem najbardziej odosobnione i najbardziej zdolne do wewnętrznego, skrytego zwrócenia się do Boga jako do czegoś, co jest możliwe" ${ }^{44}$.

Owa dobroć serca, będąca świadectwem wiary, nie może być odosobnionym i sporadycznym gestem, zewnętrznie eksponowanym „na użytek” ewangelizacji. Winna być „stylem życia” tego, kto podejmuje głoszenie Chrystusowej Ewangelii. Kard. J. Ratzinger podkreśla, że „ewangelizacja to nie tylko pewna forma mówienia, ale pewna forma życia: ewangelizować znaczy żyć słuchając głosu Ojca i stając się jego głosem. [...] Ta chrystologiczna i pneumatologiczna forma ewangelizacji jest zarazem formą eklezjologiczną: Chrystus i Duch budują Kościół, udzielają się w Kościele. Głoszenie Chrystusa, głoszenie Królestwa Bożego wymaga słuchania Jego głosu w głosie Kościoła"45. Żeby faktycznie miało to charakter ewangelizujący, ów „styl życia” winien promieniować pewnością wyznawanej wiary i przekonaniem w realizowaniu norm moralnych. Wszyscy zaś duszpasterze winni pamiętać, że „jeżeli istnieje dzisiaj szansa zostania narzędziem w ręku Boga wobec człowieka obojętnego, to o tyle tylko, o ile z całej osobowości księdza, jakby w sposób naturalny, promieniować będzie pewność - i to pewność oparta na niewzruszonej opoce Boga i wiary"46. Mając to na uwadze, kard. J. Ratzinger przypomina, że głosząc Ewangelię należy starać się o to, „aby głos Boży był słyszany i zrozumiany. Nie chcemy, aby słuchano nas dla nas samych, nie próbujemy powiększać władzy i zasięgu naszych instytucji, ale pragniemy służyć dobru człowieka i ludzkości tworząc przestrzeń dla Tego, który jest życiem. To wyrzeczenie się własnego »ja» i ofiarowanie go Chrystusowi za zbawienie ludzi jest podstawowym warunkiem prawdziwej służby Ewangelii”47.

Postawa wyrzeczenia się własnego »ja» i ofiarowanie się Chrystusowi wyraża się w poświęceniu się drugiemu człowiekowi. „Bezinteresowność tej postawy i tych działań - podkreśla Jan Paweł II - stanowiąca głęboki kontrast z egoizmem obecnym w każdym człowieku, rodzi konkretne pytania, które otwierają na Boga i na Ewangelię" ${ }^{48}$. To otwarcie się na Boga i Ewangelię ma miejsce zwłaszcza wtedy, gdy głoszący te prawdy wykaże zainteresowanie

${ }^{44}$ Tamże. Por. G. Lescanne, Maturation humaine et croissance de la foi, „Christus” 37 (1990), nr 146, s. 141-146.

${ }^{45}$ J. Ratzinger, Przemówienie prefekta Kongregacji Nauki Wiary do katechetów i nauczycieli religii 10.12.2000 r., http://www.diecezjalne.katowice.opoka.org.pl./2001/04/32.html (16.01.2004), s. 3 .

${ }^{46} \mathrm{~J}$. Loew, Osobisty kontakt duszpasterski z niewierzacymi, dz. cyt., s. 134. Por. D. A. Seeber, Nachchristlich ist nicht nichtchristlich, „Herder Korrespondenz” 36 (1982), z. 8, s. 365-366.

${ }^{47}$ J. Ratzinger, Przemówienie prefekta Kongregacji Nauki Wiary do katechetów i nauczycieli, dz. cyt., s. 2.

${ }^{48}$ Jan Paweł II, Encyklika „Redemptoris missio”, 42. 
najbardziej bliskimi problemami człowieka takimi, jak: ubóstwo, cierpienie, zapomnienie przez innych itp. Do tych zagadnień należą też: sprawiedliwość, prawa człowieka, pokój, rozwój osoby ludzkiej i inne. Podjęcie tego rodzaju tematów i problemów w ramach głoszenia Słowa Bożego jest wyrazem dawania świadectwa Chrystusowi, który „nie przyszedł, aby Mu służono, lecz żeby służyć i dać swoje życie na okup za wielu” (Mk 10,45). Znakiem wierności Ewangelii i sposobem pobudzania do otwierania się na Boga jest również podejmowanie problemów Ojczyzny, swego narodu i jego kultury, zawsze z zachowaniem wolności w Chrystusie, która otwiera na powszechne braterstwo dzieci Bożych. Dawaniem świadectwa Chrystusowi i ukierunkowaniem na Niego innych jest „odważne i profetyczne stanowisko wobec korupcji świata politycznego czy ekonomicznego, nie szukając dla siebie chwały i dóbr materialnych, używając własnych dóbr na służbę najuboższym, naśladując prostotę życia Chrystusa" ".9. Człowiek obojętny na wartości religijno-moralne, stykając się $\mathrm{z}$ tego rodzaju zaangażowaniem w problemy ludzkie, ma możliwość doświadczenia swoistej „sakralności”, a tym samym poznania Boga i Jego miłości.

Kolejną formą ewangelicznego świadectwa wobec osób indyferentnych jest „świadectwo pokory” głoszących słowo Boże. Jest to niewątpliwie trudna forma ewangelizowania, ale bardzo aktualna i potrzebna. Jan Paweł II przypomina, że wobec szerzącego się indyferentyzmu „synowie Kościoła muszą zadać sobie pytanie: w jakiej mierze i oni ulegli atmosferze sekularyzmu i relatywizmu etycznego? Jaką część odpowiedzialności za szerzącą się coraz bardziej niewiarę winni wziąć na siebie, ponieważ nie umieli ukazywać prawdziwego oblicza Boga na skutek »braków« w ich własnym życiu religijnym, moralnym i społecznym" ${ }^{\text {"50. }}$. Tego rodzaju ewangeliczne świadectwo wyraża się „W umiejętności dokonywania rachunku sumienia na płaszczyźnie osobistej i wspólnotowej, by korygować we własnym postępowaniu wszystko to, co jest antyewangeliczne i zniekształca oblicze Chrystusa" ".51. Niekiedy taka forma ewangelizowania może okazać się jedynym sposobem wywołania religijno-moralnego niepokoju u ludzi obojętnych oraz zaczątkiem ukierunkowania ich na Boga i Jego wolę.

Omawiane dotychczas formy głoszenia Słowa Bożego są przejawem ludzkiej aktywności i wysiłku. Nie można jednak zapominać, że w przezwyciężaniu religijnej obojętności przede wszystkim należy zwrócić się do Boga i Jemu powierzyć ludzi i ich sytuację. Kard. J. Ratzinger podkreśla, że same ludzkie „słowa i sztuka przekazu nie mogą przebić się do głębi człowieka, do których musi dotrzeć Ewangelia. [...] »Jezus nauczał w dzień, a modlił się w nocy«. [...] Jezus musiał zdobywać uczniów wimieniu Boga. To samo dotyczy nas. Nie mamy zdobywać ludzi dla siebie. Mamy ich zdobywać dla Boga w imieniu Boga.

${ }^{49}$ Tamże, 43. Por. W. Dleixner, Werte und Wertbeheuptung. Von der Notwendigkeit sozialer Werte, „Pastoralblatt” 6 (1993), s. 177-178.

${ }^{50}$ Jan Paweł II, List A postolski „Tertio millennio adveniente”, 36.

${ }^{51}$ Tenże, Encyklika „Redem ptoris missio”, 43. 
Wszystkie metody są jałowe, jeśli nie mają fundamentu w modlitwie. Przepowiadane słowo musi zawsze wypływać z głębokiego życia modlitewnego" ${ }^{\text {".52. }}$.

Naśladując Jezusa w przepowiadaniu Ewangelii, należy pójść jeszcze dalej i posługiwać się „,bronią samego Chrystusa, tzn. przeżyciem na nowo agonii ogrójcowej, męki i śmierci Zbawiciela"53. Stąd też ewangelizowanie osób obojętnych to „zgoda na Chrystusowy Krzyż”, to „jakby zstąpienie »do piekieł «, doświadczenie lęku opuszczenia, które podjął Chrystus, aby przywrócić człowieka Ojcu Niebieskiemu”.54. Przeżywane przez ewangelizującego tego typu doświadczenie, „przeniknięte duchem Chrystusowej Ofiary, jest niczym niezastąpionym pośrednikiem i sprawcą dóbr nieodzownych dla zbawienia świata. To ono, bardziej niż cokolwiek innego, toruje drogę łasce przeobrażającej dusze ludzkie"55. Taki wzór ewangelizowania daje nam sam Jezus Chrystus. „Całe Jego życie było wędrówką ku krzyżowi, drogą do Jerozolimy. Jezus nie odkupił świata pięknymi słowami, ale swoim cierpieniem i śmiercią. Jego męka jest niewyczerpanym źródłem życia dla świata; męka nadaje moc Jego słowom":56. Niezwykle wymowne są w tym względzie słowa św. Augustyna, który wyjaśniając Chrystusową zapowiedź męczeństwa Piotra i nakaz pasienia owiec stwierdza: „»Paś owce moje« znaczy »cierp za moje owce«”.57.

$* * * *$

Poszukiwanie coraz doskonalszych sposobów głoszenia Ewangelii jest problemem otwartym i zadaniem ciągle aktualnym. Reasumując nasze refleksje w tym zakresie, raz jeszcze w’óćmy do myśli i słów kard. J. Ratzingera. Nawiązując do rozwoju myśli teologicznej niemieckiego teologa J. B. Metza, stwierdza on, że Metz ma rację gdy podkreśla, że „prawdziwym problemem naszej epoki jest »kryzys Boga«, nieobecność Boga zamaskowana pusta religijnością. Teologia musi na powrót stać się teologią, rozmową o Bogu i z Bogiem. [...] dla człowieka prawdziwym unum necessarium jest Bóg. Wszystko zmienia się w zależności od tego, czy Bóg istnieje, czy nie istnieje. Niestety, także my chrześcijanie żyjemy często tak, jak gdyby Bóg nie istniał (si Deus non daretur). Żyjemy zgodnie z hasłem: Boga nie ma, a jeśli jest, to nie ma znaczenia" ".s. Mając na względzie taką sytuację wiary i życia moral-

\footnotetext{
52 J. Ratzinger, Przemówienie prefekta Kongregacji Nauki Wiary do katechetów i nauczycieli religii, dz. cyt., s. 3 .

${ }_{53}$ S. Rosik, Sumienie - problem żywotny wspótczesności, w: P. Morciniec (red.) Ad libertatem in veritate, dz. cyt., s. 123.

${ }^{54}$ Tamże. Por. J. Zabielski, Ludzie sumienia - problem i wezwanie naszych czasów, „Collectanea Theologica” 67 (1997), nr 3, s. 160-161.

${ }^{55}$ Jan Paweł II, List A postolski „Salvifici doloris”, 27.

${ }^{56} \mathrm{~J}$. Ratzinger, Przemówienie prefekta Kongregacji Nauki Wiary do katechetów i nauczycieli religii, dz. cyt., s. 3 .

${ }^{57}$ Św. Augustyn, Sermo 32, PLS 2, 640.

${ }_{58}$ J. Ratzinger, Przemówienie prefekta Kongregacji Nauki Wiary do katechetów i nauczycieli religii, dz. cyt., s. 5 .
} 
nego, w kontekście zadań ewangelizacyjnych dodaje: „Dlatego ewangelizacja musi mówić przede wszystkim o Bogu, musi głosić jedynego prawdziwego Boga: Stwórcę, Uświęciciela, Sędziego. [...] Jeśli zastanowimy się głębiej nad chrześcijańskim orędziem, nie będziemy mówić o wielu różnych sprawach. Chrześcijańskie orędzie jest w istocie rzeczy bardzo proste. Mówmy o Bogu i o człowieku, a powiemy wszystko" ${ }^{p 9}$. 